\title{
The Public Administration Effectiveness in the Field of Environmental Safety on the Example of Industrial Regions of the Russian Federation
}

\author{
Dmitry Rodnyansky \\ Kazan Federal University \\ Kazan, Russia \\ drodnyansky@gmail.com
}

Svetlana Shahvatova

Russian Presidential Academy of National Economy and Public Administration, Lipetsk branch

Lipetsk, Russia

ssha@mail.ru

Andrei Grafov

Russian Presidential Academy of National Economy and Public Administration, Lipetsk branch

Lipetsk, Russia

grafav@mail.ru

\author{
Ivan Makarov \\ Russian Presidential Academy of National Economy and \\ Public Administration, Lipetsk branch \\ Lipetsk, Russia \\ excellennz@gmail.com
}

Anastasia Ovodova

Kazan Federal University

Kazan, Russia

ovodova98.basket@mail.ru

Elena Ryazantseva

Russian Presidential Academy of National Economy and Public Administration, Lipetsk branch

Lipetsk, Russia

elena_18_02_83@mail.ru

\section{INTRODUCTION}

Abstract- - In the article we considered the effectiveness of
public administration in the field of environmental safety on the example of industrial regions of the Russian

Federation: Chelyabinsk region, Sverdlovsk region and Krasnoyarsk region.

The analysis showed that in these regions there is an unfavorable situation with an increase in mortality from neoplasms and respiratory diseases; and also that there is a correlation between the mortality rate from respiratory diseases and the amount of pollutant emissions into the atmosphere and the discharge of polluted wastewater. In the considered regions, there is also a general increase in the industrial production index, exceeding the growth in environmental protection costs.

These data allow us to talk about inefficiency in some aspects of public administration in the field of environmental safety.

The revealed dependencies can be used to justify some recommendations: the need to involve public organizations, movements and the population in environmental protection, toughen environmental standards, and increase regional powers in the field of environmental safety.

Keywords: public administration, environmental safety, industrial regions
The rapid development of society has not only a positive effect. And this is a long recognized fact. Man-made impact on the ecosystems of the planet often leads to devastating and irreversible consequences. That is why management in the field of environmental safety in the modern state is one of the key areas of management.

Environmental safety is the permissible level of influence of external factors, which ensures the state of protection of the planet's ecosystem and basic human interests from the negative effects of production activities, emergency situations of various nature and their consequences.

Public administration in the field of environmental safety is the activity of the state aimed at maintaining an acceptable level of negative impact of external factors on the environment

\section{LITERATURE REVIEW AND RESEARCH METHODS}

The significance of the environment and the issues of its conservation for a long time are of interest to many authors. Someone seeks to understand the scientific component of sustainable development, invent new resources and and basic human interests [1]. 
environmentally friendly methods for their use. And for someone it is important to understand what should be the effective management of resources (human, natural, technogenic) in order to minimize the damage to the environment. We can list several major publications that study these issues: «Environmental Nanotechnology, Monitoring \& Management», editors-in-Chief: P.R. Gardinali (Florida International University, Miami, Florida, USA) and P. Verlicchi (Università di Ferrara, Ferrara, Italy); «Process Safety and Environmental Protection», editors in Chief: Professor Adisa Azapagic (The University of Manchester School of Chemical Engineering and Analytical Science, Manchester, United Kingdom) and Professor Faisal Khan (Memorial University of Newfoundland, St John's, Newfoundland and Labrador, Canada); Environmental Science \& Policy, Editor in Chief: M. Beniston (University of Geneva Institute of Environmental Sciences, Carouge, Switzerland).

The dependence of environmental policy and the quality of life of the population was considered by Ryan Bosworth,Trudy Ann Cameronb, J.R. DeShazoc in work «Demand for environmental policies to improve health: Evaluating community-level policy scenarios»[2]. In this work, the need for environmental policy of the state to improve public health was assessed. The authors revealed the dependence of mortality and health indicators on the amount of resources spent on the implementation of environmental policies.

The problems of sustainable development are indeed key in the modern world and are of concern to many authors. Economic growth, good living conditions and environmental protection are important to everyone. This opinion is shared by the authors of the article, «Dissemination of Environmental Information and its Effects on Stakeholders' DecisionMaking: A Comparative Study between Swedish and Polish Municipalities» Anna Cregård and Iwona Sobis[3]. This article focuses on environmental sustainability. It examined the place of municipalities in protecting the natural environment and disseminating information about it among interested parties. This study shows that the dissemination of environmental information has a positive impact on decisionmaking by internal stakeholders. In both countries, municipal authorities follow the recommendations of the EU, which leads to innovative work and increased environmental awareness among municipal authorities, residents and other interested parties. The improvement of the natural environment is perceived by the authors as a necessity in the future. However, especially large municipalities face problems because the production and dissemination of environmental information is time-consuming. In the long run, however, a positive impact on local environmental protection is planned.

Another important aspect in implementing the concept of sustainable development is the analysis of corporate social responsibility of companies and its compliance with the environmental policy of the region. Because only the effective interaction of state institutions and corporations that have a huge impact on the quality of the environment can ensure environmental safety. This topic has been raised in the works of authors such as: "What companies do not disclose about their environmental policy and what institutional pressures may do to respect» Mitzi Isabel Cubill-Montilla, Purificación Galind-Villardón, Ana Belén Nieto- Librero, María Purificación Vicente Galindo,Isabel María García-Sánchez[4]; «The role of business strategy and CEO compensation structure in driving corporate social responsibility: Linkage towards a sustainable development perspective» Chih - Wei Peng[5]; «Does environmental regulation policy help improve green production performance? Evidence from China's industry» Chao Wang, Yue - Jun Zhang[6]; «Nexus of institutional pressures, environmentally friendly business strategies, and environmental performance» Abdul Majid Muhammad Yasir Muhammad Yasir Asad Javed[7]; «A holistic approach to manage environmental quality by using the Kano model and social cognitive theory» Elina Dace, Agnis Stibe, Lelde Timma[8]; «Green Human Resource Management and Employee Green Behavior: An Empirical Analysis» Richa Chaudhary[9].

The need to combine market mechanisms and a strong regulatory framework in the field of environmental safety is extremely important. This topic was raised by the authors of the article. «UN environmental policy: Non-State Actors, trends, and the regulatory role of the state» Joseph S. Weiss, Zhu Dajian, Maria Amélia Enríquez, Peter H. May, Elimar Pinheiro do Nascimento, Walter A. Pengue, Stanislav Shmelev [10]. The article considers the possible mechanisms of interaction between the UN, civil society organizations and transnational corporations (TNCs) in the implementation of environmental policy. Strengthening the competence of the national government and law enforcement potential, as well as binding UN agreements are necessary for the effectiveness of market incentives that can be strengthened by business and civil society initiatives. If civil society organizations unite, they will be able to implement the necessary environmental policy on equal terms with TNC.

The problem of the relationship between political economy and the impact on the human environment is relevant and enjoys increased attention of authors and publications. There are even publications that focus only on this issue with a specific approach to political ecology. For example, «Journal of Political Ecology» (editors: Professor Simon P J Batterbury, Professor Casey Walsh) [11].

The following authors dealt with specific mechanisms of public administration in this area: Francesco Rosati «Business contribution to the Sustainable Development Agenda: Organizational factors related to early adoption of SDG reporting» [12], «Nonprofit Organizations in Environmental Management: A Comparative Analysis of Government Impacts» Sara J. S. Nikolic, Tomas M. Koontz[13]; «Sponsorship Matters: Assessing Business Participation in Government- and Industry-Sponsored Voluntary Environmental Programs» Nicole Darnall, Matthew Potoski, Aseem Prakash[14]; «Environmental Politics and the Bureaucracy» Richard Waterman, Amelia Rouse, and Robert Wright[15]; «Contextual Changes and Environmental Policy Implementation: A Longitudinal Study of Street-Level Bureaucrats in Guangzhou, China» Xueyong Zhan, Carlos Wing-Hung Lo, Shui-Yan Tang[16]; «Assessment of the Environmental Tax System in Latvia» Māris Jurušs, Jānis 


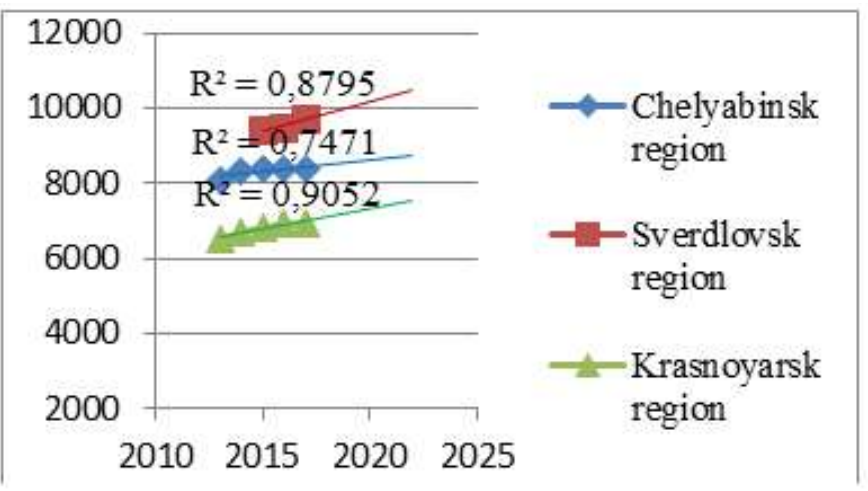

Fig. 1. Neoplasm mortality trend line from 2013 to 2022

A comparison was also made of the composition of mortality in Russia and the studied regions, on the basis of which the data presented in table I were obtained.

TABLE I. MORTALITY FROM NEW FORMATIONS, \% OF TOTAL MORTALITY

Environmental management in modern conditions of development of society should be aimed, first of all, at preserving the environment. Therefore, in many respects, the effectiveness of eco-management depends on how much attention is paid to environmental problems in the region, whether environmental protection measures are adequately funded, and whether environmental monitoring is carried out properly and in proper volume.

According to the World Health Organization, 25\% of all deaths in the world (about 13 million people) are caused by environmental pollution [21]. "Leaders" among the causes of mortality are diseases of the organs of the cardiovascular system, cancer and diseases of the respiratory system. The study also says that 6.5 million people die annually directly from air pollution.

In connection with this study, to assess the effectiveness of environmental management in industrial regions, it seems necessary to analyze the dependence of the following indicators of the region: atmospheric emissions from stationary sources, wastewater discharge, industrial production index, regional mortality, neoplasm mortality, and respiratory disease mortality environmental costs.

To begin with, a negative trend that has arisen in all regions should be noted. In Fig. 1. a linear forecast for 5 years ahead is presented, which demonstrates a further increase in mortality from neoplasms. A confidence coefficient of approximation R2 greater than 0.7 indicates a high accuracy of the forecast.

\begin{tabular}{|c|c|c|c|c|c|}
\hline Region/year & $\mathbf{2 0 1 3}$ & $\mathbf{2 0 1 4}$ & $\mathbf{2 0 1 5}$ & $\mathbf{2 0 1 6}$ & $\mathbf{2 0 1 7}$ \\
\hline Chelyabinsk region & 16.74 & 17.25 & 17.25 & 17.51 & 18.40 \\
\hline Sverdlovsk region & - & - & 15.37 & 15.56 & 16.86 \\
\hline Krasnoyarsk region & 17.93 & 18.50 & 18.77 & 19.28 & 19.60 \\
\hline Russian Federation & 15.39 & 14.95 & 15.47 & 15.87 & 17.43 \\
\hline
\end{tabular}

Several conclusions can be drawn from the table data:

- The proportion of deaths from neoplasms is increasing not only in the regions, but also in the Russian Federation.

- The proportion of deaths from neoplasms in the Chelyabinsk Region and Krasnoyarsk Territory significantly exceeds the same indicator in Russia.

By analogy with the previous table, a comparison was made of the regions and the Russian Federation in terms of mortality from respiratory diseases. The data are presented in table II.

The data obtained indicate that in the Krasnoyarsk Territory the percentage of deaths from respiratory diseases significantly exceeds the same indicator for Russia. Chelyabinsk and Sverdlovsk regions are in equal position, both among themselves and with the indicator of the Russian Federation.

TABLE II. MORTALITY FROM RESPIRATORY DISEASES, \% OF TOTAL MORTALITY

\begin{tabular}{|c|c|c|c|c|c|}
\hline Region/year & $\mathbf{2 0 1 3}$ & $\mathbf{2 0 1 4}$ & $\mathbf{2 0 1 5}$ & $\mathbf{2 0 1 6}$ & $\mathbf{2 0 1 7}$ \\
\hline $\begin{array}{c}\text { Chelyabinsk } \\
\text { region }\end{array}$ & $4.66 \%$ & $4.39 \%$ & $3.90 \%$ & $3.45 \%$ & $3.44 \%$ \\
\hline $\begin{array}{c}\text { Sverdlovsk } \\
\text { region }\end{array}$ & - & - & $3.47 \%$ & $3.21 \%$ & $3.18 \%$ \\
\hline $\begin{array}{c}\text { Krasnoyarsk } \\
\text { region }\end{array}$ & $5.48 \%$ & $5.49 \%$ & $5.30 \%$ & $4.63 \%$ & $5.12 \%$ \\
\hline $\begin{array}{c}\text { Russian } \\
\text { Federation }\end{array}$ & $3.91 \%$ & $4.03 \%$ & $3.91 \%$ & $3.72 \%$ & $3.67 \%$ \\
\hline
\end{tabular}


The next step was to collect information on the amount of emissions into the air and the discharge of polluted wastewater into surface water bodies, the data are presented below in table 3.

TABLE III. EMISSIONS OF POLLUTING SUBSTANCES TO THE ATMOSPHERE FROM STATIONARY SOURCES, THOUSAND TONS

\begin{tabular}{|c|l|l|l|l|l|l|l|l|}
\hline Region/year & $\mathbf{2 0 1 0}$ & $\mathbf{2 0 1 1}$ & $\mathbf{2 0 1 2}$ & $\mathbf{2 0 1 3}$ & $\mathbf{2 0 1 4}$ & $\mathbf{2 0 1 5}$ & $\mathbf{2 0 1 6}$ & $\mathbf{2 0 1 7}$ \\
\hline Chelyabinsk region & 749 & 694 & 678 & 667 & 653 & 627 & 597 & 533 \\
\hline Sverdlovsk region & 1169 & 1091 & 1129 & 1097 & 1021 & 984 & 906 & 928 \\
\hline Krasnoyarsk region & 2491 & 2517 & 2583 & 2497 & 2356 & 2476 & 2363 & 2371 \\
\hline
\end{tabular}

Observing the presented data, one can notice a trend towards a decrease in the amount of pollutant emissions into the atmosphere in the regions, but the situation is stable only for the Chelyabinsk region.

In the process of collecting these statistics [22], two hypotheses were put forward: the first that the number of deaths from respiratory diseases depends on the amount of pollutant emissions into the atmosphere, the second that the number of deaths from respiratory diseases depends on the amount of polluted water discharged. To verify these hypotheses, a correlation analysis of these indicators was carried out. The first calculation is presented in table IV.

TABLE IV. CORRELATION OF EMISSIONS OF POLLUTING SUBSTANCES TO THE ATMOSPHERE FROM STATIONARY SOURCES AND MORTALITY FROM RESPIRATORY DISEASES

\begin{tabular}{|c|c|}
\hline Chelyabinsk region & 0.930193293 \\
\hline Sverdlovsk region & 0.768977172 \\
\hline Krasnoyarsk region & 0.502762144 \\
\hline
\end{tabular}

Given that the value of the correlation coefficient from 0.9 to 1 is very high, from 0.7 to 0.9 high, from 0.5 to 0.7 noticeable, and from 0.3 to 0.5 moderate, we can conclude, that this correlation analysis shows that there is a dependence between the studied indicators.

The greatest correlation is observed in the Chelyabinsk region, the Sverdlovsk region also shows a high correlation of these indicators. The data of the Krasnoyarsk Territory indicate that mortality from respiratory diseases depends not only on emissions of pollutants into the atmosphere from stationary sources.

The next step was a correlation analysis of the dependence of the discharge of contaminated wastewater into surface water bodies and mortality from respiratory diseases. It is presented in table $\mathrm{V}$.

TABLE V. CORRELATION OF DISCHARGE OF CONTAMINATED WASTE WATER TO SURFACE WATER OBJECTS AND MORTALITY FROM RESPIRATORY DISEASES

\begin{tabular}{|c|c|}
\hline Chelyabinsk region & 0.217421767 \\
\hline Sverdlovsk region & 0.999905566 \\
\hline Krasnoyarsk region & 0.790000361 \\
\hline
\end{tabular}

This correlation analysis shows that in the Sverdlovsk Region and Krasnoyarsk Territory, mortality from respiratory diseases is particularly correlated with the amount of polluted wastewater discharged. But the hypothesis is not fully confirmed, since in the Chelyabinsk region these indicators are not dependent on each other.

The next step was considered the dependence of the index of industrial production of the regions and their costs for environmental protection. The data are presented below in table VI.

\section{TABLE VI. INDUSTRIAL INDEX CORRELATION AND} ENVIRONMENTAL COSTS

\begin{tabular}{|c|l|}
\hline Chelyabinsk region & -0.66288 \\
\hline Sverdlovsk region & 0.625546 \\
\hline Krasnoyarsk region & -0.6259 \\
\hline
\end{tabular}

The correlation level presented in the table indicates the following: in the Chelyabinsk Region and Krasnoyarsk Territory, a moderate inverse relationship (with an increase in the industrial production index, environmental protection costs decrease), and in the Sverdlovsk Region the direct dependence is moderate.

According to statistics provided by the Center for Political and Economic Reforms for 2018, the Chelyabinsk and Sverdlovsk Regions were included in the TOP 10 regions with the largest protests in terms of numbers. In the same dozen, for comparison, were the Moscow region and St. Petersburg. Moreover, according to the data of the same center for political and economic reforms, $7.3 \%$ of all shares in the country were caused by environmental factors. This fact largely explains the presence of the two regions studied by us in the list of the most protesting subjects of the Russian Federation.

In 2005, the Russian Copper Company built in the city of Polevskoy, Sverdlovsk Region, the company Uralhydromed JSC on the basis of the Gumeshevsky copper ore deposit discovered in 1758. This complex was the first in Russia in the hydrometallurgical production of cathode copper. This production method is carried out by introducing acidic solutions into the wells that interact with the ore, after which the solution is pumped out and sent for electrolysis. The production capacity of the enterprise is more than 5 thousand tons of cathode copper per year.

In recent years, social tension has been growing rapidly: city residents complain that Uralhydromed JSC unauthorizedly drains sulfuric acid into groundwater in the immediate vicinity of the private sector. According to statistics from Rospotrebnadzor, the number of cancer patients in Polevskoy over the year increased by $20 \%$. This is associated with the ingress of toxic substances into drinking water, since the enterprise's storage is separated from the water sources by a dam that has created a breach.

The stress in Nizhny Tagil is also high, caused by an increase in the number of allergic diseases in children and adults. Local residents complain of constant smog and atmospheric emissions from the Nizhny Tagil Metallurgical Combine. At one of the meetings to stimulate the use of natural gas in the form of motor fuel, the plight of this city was mentioned by the President of the Russian Federation, 
calling the environmental problems particularly acute. Along with Tagil, the President named Chelyabinsk, Magnitogorsk, Krasnoyarsk and Norilsk.

In 2011, the Russian Copper Company expressed its desire to begin exploring the Tominsk deposit of copper-porphyry ores, which is located $10 \mathrm{~km}$ from the city of Chelyabinsk. It is included in the TOP 50 of copper deposits in the world, and was discovered back in 1957. However, the Soviet Union did not begin to develop this deposit because of the low content of pure copper in it $(0.3 \%)$, which makes its extraction economically unprofitable. The Russian Copper Company has proposed more "innovative" technologies, implying an increase in the capacity of the chemicals used, thereby indicating the possibility of building a mining and processing plant capable of producing more than 250 thousand tons of copper concentrate per year, passing 28 million tons of copper ore through itself.

The Tominsky GOK project was adopted in 2014 and included in the "Strategy for the Development of Non-Ferrous Metallurgy in Russia for 2014-2020 and for the Perspective until 2030." This caused a wide resonance among the population of the Chelyabinsk region. The most powerful social movement Stop GOK was formed, which managed to collect more than 1.000.000 signatures under a petition to the President of the Russian Federation. Nevertheless, the construction of the enterprise was supported by the authorities of the region in the person of the former governor of the Chelyabinsk region B. Dubrovsky. In this regard, the protest activity in the region has only increased and for the past 4 years, rallies, demonstrations and protests against environmental pollution have been regularly held in the cities of the region.

The situation in the region is only heating up. On November 9, 2018, the head of the city of Miass, Chelyabinsk Region, signed an agreement with Kruglogorsk GOK LLC on the allocation of land for the construction of a new mining and processing plant near Kruglaya. Environmentalists and human rights activists are sounding the alarm: Miass is standing on the shores of Lake Turgoyak - the second most transparent lake in Russia. It is also called the "Pearl of the Urals", the water in it is close to Baikal in its characteristics. Over the past 20 years, the lake has been significantly affected by anthropogenic impact, since it provides water supply to the city of Miass. Construction in the immediate vicinity of GOK can lead to irreversible environmental damage. That is why residents of the region express their discontent, on March 2, 2019, protests took place in several cities at once: Miass, Zlatoust, Chelyabinsk, in which more than 1.100 people took part.

Each of these enterprises can give the region about 2.000 jobs. But how correctly prioritized by the state? According to the Federal Statistics Service in the Chelyabinsk and Sverdlovsk regions, the number of people diagnosed with respiratory diseases and malignant tumors is growing.

Social tension in the regions reaches catastrophic proportions: people intend to leave for other regions of Russia and take relatives. New environmental petitions are regularly signed. Residents of large industrial cities of the Urals daily share photos of urban smog, smoking chimneys of factories. The Urals are the land of lakes, the border between Europe and Asia, the national parks of Taganay, Zyuratkul, Iremel, and incredibly beautiful nature. And the inhabitants of this region want to preserve their wealth, the wealth of their country.

\section{DisCUSSION}

Based on all the data obtained, conclusions can be drawn about the effectiveness of environmental management in the studied regions:

- in spite of the trend of an increase in environmental protection costs, subjects in the all-Russian environmental rating consistently occupy low positions. This suggests that the general situation consists of several indicators, some of which are not developing;

- in the regions, the difficult situation is in the field of mortality from neoplasms and respiratory diseases. There is a steady increase in these indicators;

- the dependence of mortality on respiratory diseases and the amount of pollutant emissions into the atmosphere and the discharge of polluted wastewater is traced;

- there is a trend towards a decrease in the amount of pollutants in the atmosphere and surface water bodies, but the situation is not stable in all regions;

- there has been a general increase in the industrial production index, which exceeds the growth of environmental protection costs by an average of $2 \%$.

Evaluation of the effectiveness of environmental management in industrial regions of the Russian Federation using the example of the Chelyabinsk region, Sverdlovsk region and the Krasnoyarsk Territory revealed important correlation dependencies: mortality from respiratory diseases depends on air emissions (in the Chelyabinsk region and Krasnoyarsk Territory) and wastewater discharge (in Sverdlovsk areas), an increase in the industrial production index leads to lower environmental costs.

An analysis was also made of the statistical data on mortality from respiratory diseases and neoplasms, which showed that in these regions these indicators are higher than in the Russian Federation.

- Based on the analysis and foreign experience of public administration in the field of environmental safety, the following recommendations can be proposed:

- Increasing the powers of the regions in environmental management;

- Attracting public organizations, movements and the population to participate in environmental protection;

- Introduction of regional, municipal referenda on important environmental issues;

- Tighter environmental standards, equating them with international ones; 
- Introduction of the concept of "white metallurgy" in industrial regions, investment in the environment.

\section{CONCLUSION}

In this article, the authors discovered and mathematically confirmed important hypotheses: the mortality rate from respiratory diseases depends on the level of emissions into the air and the discharge of wastewater. This fact suggests the need to take measures to reduce the harmful effects of industrial facilities in order to increase the main indicators of health care: reducing mortality and increasing life expectancy. The second identified problem indicates that the more actively industrial production develops, the lower the regional costs for environmental protection. According to the authors, in this case, it is just necessary to maintain the proportional development of these indicators: the larger the production, the greater the cost of eliminating the negative technological effects.

This research makes it possible to predict the damage caused to the demographics of the regions and the country as a whole, provided that the level of government in the field of environmental safety remains at the same level and no measures are taken to tighten environmental legislation, decentralize decisions on environmental issues and application of successful foreign experience.

The novelty of the author's proposals is that the issue of ensuring environmental safety is still considered the competence of regional and federal authorities, while foreign experience shows much greater efficiency in solving environmental issues at the local level. Consequently, the introduction of municipal referenda, the involvement of public organizations and the population in resolving environmental issues and the tightening of environmental standards is a new, previously unexplored for Russia, but, of course, true development path.

Sustainable development and responsibility for the environment are important components of a healthy society in Russia. The right to a favorable environment is enshrined in the Constitution [23], which means that Russia recognizes this responsibility and is ready to improve. One should not be afraid to adopt successful foreign experience, cooperate with "environmental" companies, develop a dialogue between public organizations, the public and authorities, and this will help to maintain a favorable environment, as well as give impetus to the introduction of new, safe technologies.

\section{REFERENCES}

[1] X. Zhang, X. Zhang, and X. Chen,"Happiness in the air: How does a dirty sky affect mental health and subjective well-being? ", Journal of Environmental Economics and Management, vol. 85, September 2017, pp. 81-94.

[2] R. Bosworth, T. A. Cameron, and J. R. DeShazo, "Demand for environmental policies to improve health: Evaluating community-level policy scenarios", Journal of Environmental Economics and Management, vol. 57, issue 3, May 2009, pp. 293-308.

[3] A. Cregård and I. Sobis, "Dissemination of Environmental Information and its Effects on Stakeholders' Decision-Making: A Comparative Study between Swedish and Polish Municipalities", NISPAcee Journal of Public Administration and Policy, vol. X, no. 2, December 2017.

[4] M. I. Cubill-Montilla, P. Galind-Villardón, A. B. Nieto- Librero, M. P. Vicente Galindo, and I. M. García-Sánchez, "What companies do not disclose about their environmental policy and what institutional pressures may do to respect", Corporate Social Responsibility and Environmental Management, October 2019.

[5] Chih-Wei Peng, "The role of business strategy and CEO compensation structure in driving corporate social responsibility: Linkage towards a sustainable development perspective», Corporate Social Responsibility and Environmental Management, 31 October 2019.

[6] C. Wang, Y.-J. Zhang, "Does environmental regulation policy help improve green production performance? Evidence from China's industry", Corporate Social Responsibility and Environmental Management, 01 October 2019.

[7] A. M. Muhammad, Y. Muhammad Yasir, and A. Javed, "Nexus of institutional pressures, environmentally friendly business strategies, and environmental performance", Corporate Social Responsibility and Environmental Management, 20 August 2019.

[8] E. Dace, A. Stibe, and L. Timma, "A holistic approach to manage environmental quality by using the Kano model and social cognitive theory", Corporate Social Responsibility and Environmental Management, 07 August 2019.

[9] R. Chaudhary, "Green Human Resource Management and Employee Green Behavior: An Empirical Analysis", Corporate Social Responsibility and Environmental Management, 06 August 2019.

[10] J. S. Weiss, Z. Dajian, M. A. Enríquez, P. H. May, E. Pinheiro do Nascimento, W. A. Pengue, and S. Shmelev, "UN environmental policy: Non-State Actors, trends, and the regulatory role of the state", Journal of Political Ecology, vol. 24, no. 1, 2017.

[11] S. P. J. Batterbury, C. Walsh, "Journal of Political Ecology".

[12] F. Rosati, "Business contribution to the Sustainable Development Agenda: Organizational factors related to early adoption of SDG reporting", Corporate Social Responsibility and Environmental Management, 07 January 2019.

[13] S. J. S. Nikolic and T. M. Koontz, "Nonprofit Organizations in Environmental Management: A Comparative Analysis of Government Impacts", Journal of Public Administration, vol. 18, no. 3, pp. 441-463.

[14] N. Darnall, M. Potoski, and A. Prakash, "Sponsorship Matters: Assessing Business Participation in Government- and IndustrySponsored Voluntary Environmental Programs", Journal of Public Administration Research and Theory, vol. 20, no. 2, 2010, pp. 283-307.

[15] R. Waterman, A. Rouse, and Robert Wright, "Environmental Politics and the Bureaucracy", Journal of Public Administration Research and Theory, vol. 16, issue 4, October 2006, pp. 639-642.

[16] X. Zhan, C. Wing-Hung Lo, and S.-Y. Tang, "Contextual Changes and Environmental Policy Implementation: A Longitudinal Study of StreetLevel Bureaucrats in Guangzhou, China", Journal of Public Administration Research and Theory, 2013.

[17] M. Jurušs and J. Brizga, "Assessment of the Environmental Tax System in Latvia", The NISPAcee Journal of Public Administration and Policy, vol. 10, no. 2, winter 2017/2018.

[18] Q. Zhang, Z. Yu, and D. Kong, "The real effect of legal institutions: Environmental courts and firm environmental protection expenditure", Journal of Environmental Economics and Management, vol. 98, November 2019.

[19] H. Zhong, W. Hu, "Revisiting motivations for on-farm environmental practices: Opportunity wage and community effect", Journal of Environmental Management, 15 August 2019.

[20] D. Carfi, A. Donato, and D. Schiliró, "Coopetitive solutions of environmental agreements for the global economy after COP21 in Paris", Journal of Environmental Management, August 2019.

[21] Website World health organization [Electronic resource]. Available at: https://www.who.int/ru

[22] Russian statistics 2017, Federal state statistics service. M., 2017.

[23] Constitution of the Russian Federation 